Article

\title{
Enrichment Free qPCR for Rapid Identification and Quantification of Campylobacter jejuni, C. coli, C. lari, and C. upsaliensis in Chicken Meat Samples by a New Couple of Primers
}

\author{
Priya Vizzini $^{1}$ (D), Jasmina Vidic ${ }^{2}$ (D) and Marisa Manzano ${ }^{1, *(D)}$ \\ 1 Dipartimento di Scienze AgroAlimentari, Ambientali e Animali, Università di Udine, 33100 Udine, Italy; \\ vizzini.priya@spes.uniud.it \\ 2 AgroParisTech, INRAE, Micalis Institute, Université Paris-Saclay, 78350 Jouy en Josas, France; \\ jasmina.vidic@inrae.fr \\ * Correspondence: marisa.manzano@uniud.it
}

check for

updates

Citation: Vizzini, P.; Vidic, J.;

Manzano, M. Enrichment Free qPCR

for Rapid Identification and

Quantification of Campylobacter jejuni,

C. coli, C. lari, and C. upsaliensis in

Chicken Meat Samples by a New

Couple of Primers. Foods 2021, 10,

2341. https://doi.org/10.3390/

foods10102341

Academic Editor: Djamel Drider

Received: 6 September 2021

Accepted: 28 September 2021

Published: 30 September 2021

Publisher's Note: MDPI stays neutra with regard to jurisdictional claims in published maps and institutional affiliations.

Copyright: (c) 2021 by the authors Licensee MDPI, Basel, Switzerland. This article is an open access article distributed under the terms and conditions of the Creative Commons Attribution (CC BY) license (https:/ / creativecommons.org/licenses/by/ $4.0 /)$

\begin{abstract}
Campylobacter is the main cause of bacterial foodborne disease and poultry meat is the principal source of human infections. Rapid methods for Campylobacter detection are urgently needed to decrease high bacterial prevalence in poultry products. In this study, we developed new primers, CampyPFw and CampyPRv, that target the 16S-23S rRNA genes of Campylobacter jejuni, C. coli, C. lari and $C$. upsaliensis. The primers were tested on positive and negative reference strains in pure cultures and in inoculated poultry meat samples before their application in real-time PCR (qPCR) protocol for analyzing chicken meat samples. In parallel, the samples were tested by using the ISO 10272-1:2006 method. The qPCR protocol based on CampyPFw and CampyPRv showed good sensitivity, with the limit of detection of $4.6 \times 10^{2}$ cells $/ \mathrm{mL}$ in chicken samples without enrichment steps.
\end{abstract}

Keywords: Campylobacter spp.; qPCR; spiked chicken meat; foodborne pathogens

\section{Introduction}

The thermotolerant Campylobacter species, especially C. jejuni and C. coli, are the leading cause of campylobacteriosis, the zoonotic enteric infection for which its incidence has increased in both developed and developing countries in the last 10 years [1]. Campylobacter spp., the major zoonotic disease agent since 2005 [2], may cause gastroenteritis, severe septicemia bloodstream infection, inflammatory bowel disease, reactive arthritis, and Guillain-Barreé syndrome [2]. The most important source of campylobacteriosis in humans is raw or insufficiently cooked chicken meat as well as cross-contamination while handling meat contaminated with Campylobacter spp.

Campylobacter shows more than $75 \%$ prevalence in the EU member states in broiler meat $[3,4]$. Currently, samples from broiler meat and skin are analyzed by using laborconsuming and time-consuming enumeration processes that are mostly based on viable plate count methods [1]. The official culture-based methods are not suitable for routine analysis, because they provide results in 5-7 days while most of the poultry-based products are consumed within a few days. In addition, Campylobacter is a fastidious organism that loses its cultivability when poultry meat is stored at $4{ }^{\circ} \mathrm{C}$ or under oxygen, and, thus, cannot be detected by a plate count method [5-7].

Methods including microscopy and assays for the detection of metabolic activities, such as membrane potential, are sensitive and rapid but expensive and time-consuming [1,8,9]. Molecular methods, such as real-time PCR (qPCR), provide advantages in Campylobacter quantification, especially in terms of the turnaround time, specificity, and sensitivity $[10,11]$. The implementation of molecular techniques will enable rapid and accurate routine analysis, thereby preventing and/or reducing outbreaks in humans and improving 
our knowledge on Campylobacter contamination. qPCR has already been used for different purposes related to the poultry industry, including quantification in poultry carcass rinses [12-15], chilled or frozen carcass [16], fecal and cecal samples [17,18], carcasses [19], neck-skin [20,21], and samples from slaughterhouses [19,22]. Nevertheless, different steps in qPCR still have to be optimized before it can be widely accepted for identification and quantification of Campylobacter in poultry samples with low contamination levels. These limitations are mainly related to the method used for the extraction of DNA in various food matrices, the elimination of matrix inhibitors, and the detection and quantification of low number of cells per gram of foods.

In this study, a new couple of primers targeting the 16S-23S rRNA gene of the most prevalent Campylobacter spp., i.e., C. jejuni, C. coli, C. lari, and C. upsaliensis, was designed, tested, and used in qPCR for Campylobacter quantification. The qPCR assay was applied on both artificially and naturally contaminated chicken meat samples before the enrichment step (DNA extracted from the homogenization bag) and after the $48 \mathrm{~h}$ enrichment in Bolton broth (selective medium for the Campylobacter species). The results were compared with those obtained by using the plate count method and the standard method.

\section{Materials and Methods}

\subsection{Microorganisms}

The bacterial strains used in this study are listed in Table S1. All Campylobacter spp., Helicobacter spp., and Arcobacter butzleri strains were cultivated under specific microaerophilic conditions $\left(6 \% \mathrm{O}_{2}, 7 \% \mathrm{CO}_{2}, 7 \% \mathrm{H}_{2}\right.$, and $\left.80 \% \mathrm{~N}_{2}\right)$ generated by using an Oxoid ${ }^{\mathrm{TM}}$ Campy$\mathrm{Gen}^{\mathrm{TM}} 2.5 \mathrm{~L}$ sachet (Thermo Fisher Scientific Inc., Milan, Italy). The revitalization procedure of cultures stored at $-80^{\circ} \mathrm{C}$ was conducted at $37^{\circ} \mathrm{C}$ for $48 \mathrm{~h}$ in brain-heart infusion (BHI) broth (Thermo Fisher Scientific Inc., Milan, Italy). Furthermore, the Campylobacter isolates were incubated in Columbia blood agar base (Thermo Fisher Scientific Inc., Milan, Italy) supplemented with $5 \% v / v$ of sheep defibrinated blood. Pure colonies were isolated on BHI agar medium and subjected to Gram staining, oxidase and catalase tests, and cell-morphology analyses. Strains used as negative controls were cultivated on BHI agar medium at 30 or $37^{\circ} \mathrm{C}$ for 24 or $48 \mathrm{~h}$ based on the optimum growth conditions of the microorganism, with the exception of Lactobacillus plantarum which required microaerophilic conditions. All bacteria were examined using Gram staining and cell-morphology analysis. Selective media PALCAM Agar Base, X.L.D. Agar, and Brilliance ${ }^{\mathrm{TM}}$ Bacillus Cereus Agar Base for Listeria, Salmonella, and Bacillus cereus, respectively, were purchased from Oxoid (Thermo Fisher Scientific Inc., Milan, Italy).

\subsection{Chicken Samples and Plate Count Enumeration}

Twenty chicken meat samples (named CC) purchased from local butcher shops in Italy in 2016 where they were conserved at $4{ }^{\circ} \mathrm{C}$ until purchase, were analyzed for bacterial enumeration by using the plate-count method and tryptone soya agar (TSA) at $30{ }^{\circ} \mathrm{C}$ for $48 \mathrm{~h}$. Yeasts and molds were enumerated on malt extract agar supplemented with $10 \mu \mathrm{g} / \mathrm{mL}$ tetracycline (AMT) at $30{ }^{\circ} \mathrm{C}$ for $48 \mathrm{~h}$; Enterobacteriaceae, were enumerated on violet red bile glucose agar (VRBGA) at $37^{\circ} \mathrm{C}$ for $24 \mathrm{~h}$; and E. coli and coliforms were enumerated on Coli-ID agar (Biomeriaux, Firenze, Italy) at $37^{\circ} \mathrm{C}$ for $24 \mathrm{~h}$.

Additionally, $10 \mathrm{~g}$ of each chicken sample (including skin and meat) was transferred to a Stomacher filter bag containing $90 \mathrm{~mL}$ of Bolton broth (Thermo Fisher Scientific Inc., Milan, Italy) and subjected to the ISO 10272-1:2006 method for Campylobacter spp. detection.

For the sake of confirmation, suspected colonies from each plate were streaked on blood agar base plates, half of each colony was incubated at $41.5^{\circ} \mathrm{C}$, and the other half was incubated at $25^{\circ} \mathrm{C}$ for $48 \mathrm{~h}$. Bacteria were subjected to oxidase tests and motility tests, that were carried out in Brucella broth (Thermo Fisher Scientific Inc., Milan, Italy) in order to verify the presence of the typical corkscrew-like movement used for Campylobacter spp. identification. 
Serial decimal dilutions of C. jejuni overnight culture (BHI, microaerophilic conditions, $20 \mathrm{~h}$ ) containing approximately $10^{8}$ cells $/ \mathrm{mL}$ were inoculated into meat samples (named SC) to reach final concentrations of $10^{7}, 10^{5}, 10^{3}$, and 0 cell of $C$. jejuni per g of meat.

The spiked chicken samples were analyzed by colony count on mCCDA to confirm the inoculum, and DNA was extracted and used in a qPCR assay with the new primers.

The workflow of the procedure used in this work is reported in Figure 1.

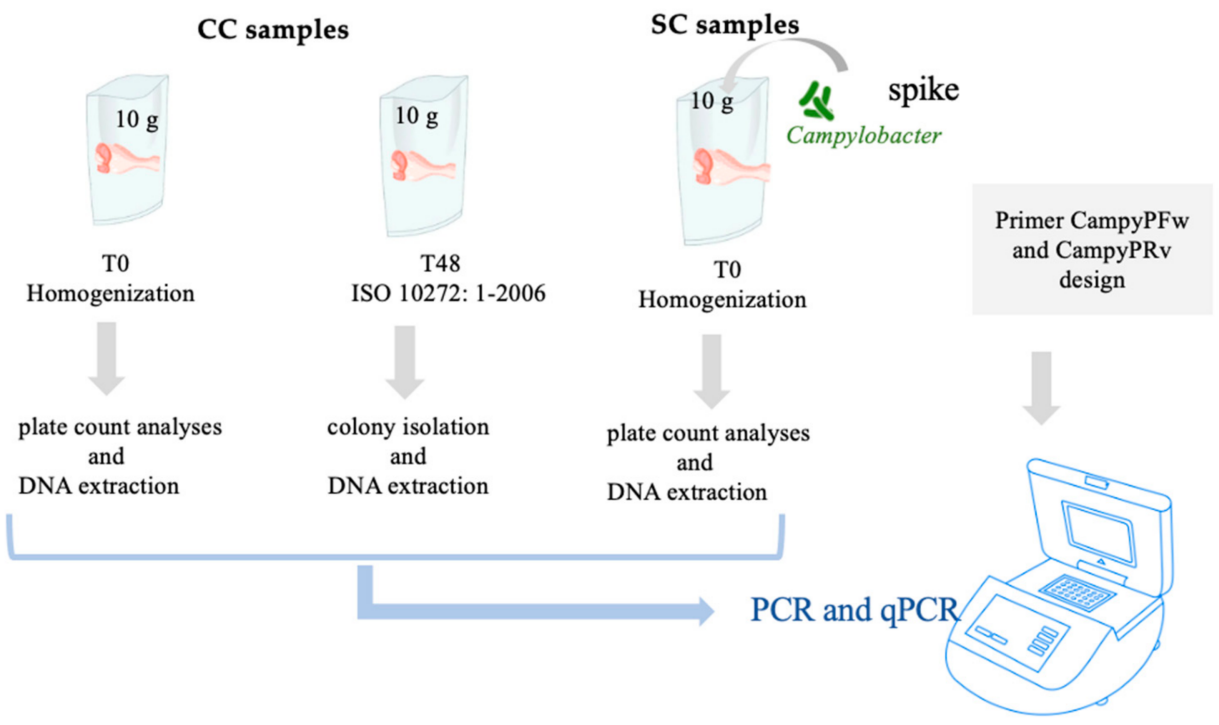

Figure 1. Workflow of the work performed for the detection of Campylobacter spp. in chicken samples.

\subsection{DNA Extraction}

DNA extractions from CC samples were carried at $\mathrm{t}_{0}\left(\mathrm{CC}_{0}\right)$ and after enrichment at $48 \mathrm{~h}$ (CCt $\left.{ }_{48}\right)$, while DNA was extracted from SC samples (spiked samples) at $\mathrm{t}_{0}\left(\mathrm{SCt}_{0}\right)$. Both DNA extractions were performed following a previously published protocol [23]: Two $\mathrm{mL}$ was collected from the Stomacher bags containing SPW at $t_{0}$ (SC and CC samples), and $2 \mathrm{~mL}$ was collected from the Bolton broth after $48 \mathrm{~h}$ ( $\mathrm{CC}_{\mathrm{t} 48}$ samples). After centrifugation at $14,000 \times g$ for $10 \mathrm{~min}$, the pellet was resuspended in $300 \mu \mathrm{L}$ of breaking buffer $(2 \%$ Triton $\mathrm{X}-100,1 \% \mathrm{SDS}, 100 \mathrm{~mm} \mathrm{NaCl}, 10 \mathrm{~mm}$ Tris $\mathrm{pH}$, and $1 \mathrm{~mm}$ EDTA pH 8) and $300 \mathrm{~mL}$ of phenol-chloroform-isoamyl alcohol 25:24:1 (Sigma, Milan, Italy) was added [24] with glass beads.

The cells were then homogenized in a bead beater (Mini-Bead Beater 8t, Biospec Products Inc., Bartlesville, OK, USA) three times, each for $30 \mathrm{~s}$ at maximum speed at room temperature. The amount of $300 \mathrm{~mL}$ of TE $(10 \mathrm{~mm}$ Tris, $1 \mathrm{~mm}$ EDTA pH 7.6) was added, and the tubes were centrifuged at $12,000 \times \mathrm{g}$ for $10 \mathrm{~min}$ at $4{ }^{\circ} \mathrm{C}$. The aqueous phase was collected, and DNA was precipitated with $1 \mathrm{~mL}$ ice-cold absolute ethanol. After centrifugation at $14,000 \times g$ for $10 \mathrm{~min}$ at $4{ }^{\circ} \mathrm{C}$, the pellet was dried under vacuum at room temperature and resuspended in $50 \mathrm{~mL}$ of sterile distilled water containing $2 \mathrm{IU}$ DNase-free RNase (Roche Diagnostics, Milan, Italy). The samples were then incubated at $37^{\circ} \mathrm{C}$ for $30 \mathrm{~min}$ before storage at $-20^{\circ} \mathrm{C}$.

DNA concentration and purity were measured using a spectrophotometer (NanoDrop, ThermoFisher Scientific Inc, Milano, Italy). The extracted DNAs were used for qPCR.

\subsection{Primer Design}

New primers CampyPFw (5'-CTTTGCACGCAGGAGGTCA-3') and CampyPRv (5'-ATGGTGGGCCTAACAAGACT- $3^{\prime}$ ) were designed in the 16S-23S gene sequences GQ167702.1 of C. jejuni; GQ167720.1 of C. coli; AB644222.1 of C. lari; and DQ871249.1 of C. upsaliensis downloaded from GenBank (http:/ /www.ncbi.nlm.nih.gov/genbank/). The software (http://multalin.toulouse.inra.fr/multalin/) for multiple sequence alignment with hierarchical clustering [25] AmplifX 1.7.0, OligoAnalyzer 3.1 (https:/ / eu.idtdna. 
com/calc/analyzer) and FastPCR6.1 were used to verify the specificity of various bacteria belonging to both the same and different genera and animal gene sequences (Table S2), as previously described [26].

\subsection{PCR and qPCR Protocols}

CampyPFw and CampyPRv primers were tested for specificity by using end-point PCR. The reaction mixture contained the following reagents: $5 \mu \mathrm{L}$ AmpliTaq buffer, $1.5 \mathrm{mM}$ $\mathrm{MgCl}_{2}, 1 \mu \mathrm{L}$ dNTPs (10 mM of each dNTP), $1 \mu \mathrm{L}$ of each primer $(10 \mu \mathrm{M}), 0.25 \mu \mathrm{L}$ AmpliTaq DNA polymerase ( 5 units $/ \mu \mathrm{L}$ ), and $1 \mu \mathrm{L}$ of DNA at $100 \mathrm{ng} / \mu \mathrm{L}$. All reagents were purchased from Applied Biosystems (ThermoFisher Scientific Inc., Milan, Italy). In each assay, a negative control where the template DNA was replaced with an equal volume of nucleasefree water (NCT) was included. A thermal cycler C1000 Touch ${ }^{\mathrm{TM}}$ (Bio-Rad Laboratories Inc., Hercules, CA, USA) was used.

Amplification conditions were as follows: denaturation at $95^{\circ} \mathrm{C}$ for $5 \mathrm{~min} ; 30$ cycles of denaturation at $95{ }^{\circ} \mathrm{C}$ for $1 \mathrm{~min}$; annealing at $58^{\circ} \mathrm{C}$ for $30 \mathrm{~s}$; extension at $72{ }^{\circ} \mathrm{C}$ for $30 \mathrm{~s}$; and a final extension at $72{ }^{\circ} \mathrm{C}$ for $7 \mathrm{~min}$. The PCR products were electrophoresed on a $1.5 \%$ agarose gel and visualized using ethidium bromide (Sigma-Aldrich Inc., Milan, Italy) at a final concentration of $0.5 \mu \mathrm{g} / \mathrm{mL}$ in a GeneGenius Biolmaging System (Syngene Ltd., Cambridge, UK). The electrophoretic run was carried out at $120 \mathrm{~V}$ for $40 \mathrm{~min}$.

A qPCR protocol with CampyPFw and CampyPRv was optimized by using a Rotorgene $Q$ thermocycler (Qiagen Inc., Milan, Italy). Calibration curves were performed using both serial dilutions of DNA in the range $10 \mathrm{ng} / \mu \mathrm{L}-100 \mathrm{fg} / \mu \mathrm{L}$ and concentrations of C. jejuni DSM 4688 cells from $10^{8}$ to 10 cell $/ \mathrm{mL}$. The PCR mixture contained the following reagents: $10 \mu \mathrm{L}$ of SsoFast ${ }^{\mathrm{TM}}$ EvaGreen Supermix $(2 \times)$ (Bio-Rad Laboratories Inc., Hercules, CA, USA), $1 \mu \mathrm{L}$ of each primer (CampyPFw and CampyPRv) at $10 \mu \mathrm{M}$, and $1 \mu \mathrm{L}$ of DNA template in a final volume of $20 \mu \mathrm{L}$. DNAs extracted from chicken samples $\mathrm{SCt}_{0}, \mathrm{CCt}_{0}$, and $\mathrm{CCt}_{48}$ were used; in each assay, a negative control was included.

The program consisted of hot-start activation at $98^{\circ} \mathrm{C}$ for $2 \mathrm{~min}, 35$ cycles of denaturation at $98^{\circ} \mathrm{C}$ for $5 \mathrm{~min}$, and annealing/extension at $60^{\circ} \mathrm{C}$ for $20 \mathrm{~s}$. Following a melting temperature analysis, a gradual increase in temperature from 60 to $95^{\circ} \mathrm{C}\left(0.5^{\circ} \mathrm{C} / 5 \mathrm{~s}\right)$ was performed.

An end-point PCR was performed for samples 2CC and 3CC and C. jejuni DSM4688 (as reference) using primers P1V1 and P4V3 [27], purified using the QIAquick PCR Purification Kit (Qiagen Inc., Milan, Italy), and sent to Eurofins Genomics Co. (Ebersberg, Germany) for sequencing. The obtained sequences were processed in BLAST [28] to confirm Campylobacter identification.

\section{Results and Discussion}

\subsection{Microbiological Analysis of Samples}

The enumerations of the total viable counts of Enterobacteriaceae, coliforms, E. coli, yeasts, and molds obtained for 20 chicken samples, using the plate count method are reported in Table 1.

The total bacterial count in CC samples ranged from $1.3 \times 10^{4}$ to $5.1 \times 10^{9} \mathrm{CFU} / \mathrm{g}$, with the exception of the $17 \mathrm{CC}$ sample which showed values below $50 \mathrm{CFU} / \mathrm{g}$ (the limit of detection of the method used). Similarly, Enterobacteriaceae count ranged from $2.1 \times 10^{2}$ to $2.4 \times 10^{4} \mathrm{CFU} / \mathrm{g}$; coliform values ranged from $1.3 \times 10^{1}$ to $3.2 \times 10^{4} \mathrm{CFU} / \mathrm{g}$, except for samples 12 CC and 17 CC, which showed values below the limit of detection of the method used. E. coli values ranged from $2 \times 10^{1}$ to $5.3 \times 10^{3} \mathrm{CFU} / \mathrm{g}$, except for the $19 \mathrm{CC}$ sample, which showed a value below the limit of detection. Yeasts ranged from $1.7 \times 10^{2}$ to $6.3 \times 10^{5}$, except for the 17 CC sample, while showed that molds were below the limit of detection in all samples. 
Table 1. Microbial enumeration obtained for chicken samples of $10 \mathrm{~g}$ analyzed for total viable count, Enterobacteriaceae, coliforms, E. coli, yeasts, and molds expressed in Colony Forming Units (CFU)/g.

\begin{tabular}{|c|c|c|c|c|c|c|}
\hline Samples & Total Viable Count & Enterobacteriaceae & Coliforms & E. coli & Yeasts & Molds \\
\hline $1 \mathrm{CC}$ & $9.9 \times 10^{7}$ & $3.8 \times 10^{3}$ & $2.0 \times 10^{3}$ & $1.7 \times 10^{3}$ & $2.3 \times 10^{4}$ & $<50 *$ \\
\hline $2 \mathrm{CC}$ & $5.1 \times 10^{5}$ & $1.1 \times 10^{3}$ & $9.8 \times 10^{1}$ & $2.0 \times 10^{2}$ & $1.9 \times 10^{3}$ & $<50 *$ \\
\hline $3 \mathrm{CC}$ & $1.9 \times 10^{5}$ & $9.4 \times 10^{2}$ & $1.3 \times 10^{1}$ & $7.4 \times 10^{2}$ & $7.8 \times 10^{2}$ & $<50 *$ \\
\hline $4 \mathrm{CC}$ & $4.8 \times 10^{6}$ & $1.2 \times 10^{4}$ & $3.0 \times 10^{3}$ & $5.3 \times 10^{3}$ & $9.4 \times 10^{4}$ & $<50 *$ \\
\hline $5 \mathrm{CC}$ & $9.5 \times 10^{6}$ & $2.1 \times 10^{4}$ & $7.0 \times 10^{3}$ & $1.3 \times 10^{3}$ & $6.3 \times 10^{5}$ & $<50 *$ \\
\hline $6 \mathrm{CS}$ & $7.3 \times 10^{5}$ & $1.7 \times 10^{3}$ & $2.3 \times 10^{3}$ & $7.6 \times 10^{2}$ & $6.6 \times 10^{4}$ & $<50 *$ \\
\hline $7 \mathrm{CC}$ & $9.6 \times 10^{5}$ & $9.2 \times 10^{3}$ & $6.4 \times 10^{3}$ & $4.7 \times 10^{2}$ & $3.3 \times 10^{4}$ & $<50 *$ \\
\hline $8 \mathrm{CC}$ & $9.8 \times 10^{4}$ & $5.2 \times 10^{3}$ & $5.2 \times 10^{3}$ & $3.2 \times 10^{2}$ & $1.5 \times 10^{3}$ & $<50 *$ \\
\hline $9 \mathrm{CC}$ & $1.8 \times 10^{5}$ & $2.7 \times 10^{3}$ & $1.4 \times 10^{3}$ & $3.5 \times 10^{2}$ & $2.2 \times 10^{3}$ & $<50 *$ \\
\hline $10 \mathrm{CC}$ & $1.3 \times 10^{4}$ & $1.5 \times 10^{3}$ & $7.7 \times 10^{2}$ & $8.3 \times 10^{1}$ & $1.7 \times 10^{2}$ & $<50$ * \\
\hline $11 \mathrm{CC}$ & $2.1 \times 10^{6}$ & $2.1 \times 10^{2}$ & $4.2 \times 10^{1}$ & $2.0 \times 10^{1}$ & $6.1 \times 10^{3}$ & $<50 *$ \\
\hline $12 \mathrm{CC}$ & $7.0 \times 10^{5}$ & $2.6 \times 10^{3}$ & $<50 *$ & $8.0 \times 10^{2}$ & $2.0 \times 10^{4}$ & $<50 *$ \\
\hline $13 \mathrm{CC}$ & $1.2 \times 10^{7}$ & $9.6 \times 10^{3}$ & $9.5 \times 10^{1}$ & $2.7 \times 10^{2}$ & $3.5 \times 10^{4}$ & $<50$ * \\
\hline $14 \mathrm{CC}$ & $1.7 \times 10^{7}$ & $2.4 \times 10^{3}$ & $3.0 \times 10^{2}$ & $0.6 \times 10^{3}$ & $5.3 \times 10^{4}$ & $<50 *$ \\
\hline $15 \mathrm{CC}$ & $3.7 \times 10^{7}$ & $6.9 \times 10^{3}$ & $6.5 \times 10^{1}$ & $2.2 \times 10^{3}$ & $4.5 \times 10^{4}$ & $<50 *$ \\
\hline $16 \mathrm{CC}$ & $1.1 \times 10^{7}$ & $1.6 \times 10^{4}$ & $5.6 \times 10^{2}$ & $2.6 \times 10^{2}$ & $2.4 \times 10^{5}$ & $<50 *$ \\
\hline $17 \mathrm{CC}$ & $<50 *$ & $3.3 \times 10^{2}$ & $<50 *$ & $3.1 \times 10^{2}$ & $<50 *$ & $<50 *$ \\
\hline $18 \mathrm{CC}$ & $3.3 \times 10^{9}$ & $2.1 \times 10^{4}$ & $3.2 \times 10^{4}$ & $6.0 \times 10^{2}$ & $4.9 \times 10^{5}$ & $<50 *$ \\
\hline $19 \mathrm{CC}$ & $3.8 \times 10^{9}$ & $5.4 \times 10^{3}$ & $1.3 \times 10^{4}$ & $<50 *$ & $3.9 \times 10^{5}$ & $<50 *$ \\
\hline $20 \mathrm{CC}$ & $5.1 \times 10^{9}$ & $2.4 \times 10^{4}$ & $2.4 \times 10^{4}$ & $1.5 \times 10^{2}$ & $5.4 \times 10^{5}$ & $<50 *$ \\
\hline
\end{tabular}

* Limit of detection of the method.

The total viable count for mesophilic microorganisms was acceptable for all chicken samples analyzed, except for 18 CC, 19 CC, and 20 CC, which were 2-3 log higher. Data obtained were in accordance with values reported in the guidelines of Piemonte Region, which are based on risk analysis in approved food microbiology. For fresh and refrigerated meat values of total viable count, mesophilic microorganisms from $10^{6}$ to $10^{7} \mathrm{CFU} / \mathrm{g}$, Enterobacteriaceae from $10^{4}$ to $10^{6} \mathrm{CFU} / \mathrm{g}$ and E. coli from $10^{3}$ to $10^{4} \mathrm{CFU} / \mathrm{g}$ are considered acceptable.

Samples 2 CC, 3 CC, 8 CC, 10 CC, 16 CC, and 17 CC were positive for the presence of Campylobacter spp. based on the results obtained by the ISO 10272-1:2006 method after 4-6 h at $37^{\circ} \mathrm{C}$ and $40-48 \mathrm{~h}$ incubation in Bolton broth (Table 2). No correlation was observed between total bacterial count and the presence of Campylobacter spp., which is in agreement with previously published results [29].

Table 2. Results of the ISO10272-1:2006 analyzing $10 \mathrm{~g}$ of chicken meat expressed as presence $(+)$ or absence $(-)$ of Campylobacter spp. by streaking on selective media mCCDA *, SKR ${ }^{\circ}$, and $\mathrm{CAB} \S$ used after $4-6 \mathrm{~h}$ at $37^{\circ} \mathrm{C}$ and $40-48 \mathrm{~h}$ at $41.5^{\circ} \mathrm{C}$ and $25^{\circ} \mathrm{C}$. Oxidase and motility tests were performed on isolates.

\begin{tabular}{|c|c|c|c|c|c|c|c|}
\hline \multirow{2}{*}{ Sample } & \multirow{2}{*}{ mCCDA * } & \multirow{2}{*}{$\mathrm{SKR}^{\circ}$} & \multirow{2}{*}{$\mathrm{CAB} \S$} & \multicolumn{2}{|c|}{ Confirmation Medium CAB } & \multirow{2}{*}{ Oxidase } & \multirow{2}{*}{ Motility } \\
\hline & & & & $41.5^{\circ} \mathrm{C}$, Aerobic & $25^{\circ} \mathrm{C}$, Microaerophilic & & \\
\hline $1 \mathrm{CC}$ & + & - & + & + & - & + & - \\
\hline $2 \mathrm{CC}$ & + & - & + & - & - & + & + \\
\hline $3 \mathrm{CC}$ & + & - & + & - & - & + & + \\
\hline $4 \mathrm{CC}$ & + & - & + & + & + & + & - \\
\hline $5 \mathrm{CC}$ & + & - & + & + & + & + & - \\
\hline $6 \mathrm{CC}$ & + & - & + & + & + & + & - \\
\hline $7 \mathrm{CC}$ & + & - & + & + & + & + & - \\
\hline $8 \mathrm{CC}$ & + & - & + & - & - & + & + \\
\hline $9 \mathrm{CC}$ & + & + & + & + & + & + & - \\
\hline $10 \mathrm{CC}$ & + & - & + & - & - & + & + \\
\hline $11 \mathrm{CC}$ & - & - & & & & & \\
\hline $12 \mathrm{CC}$ & - & - & & & & & \\
\hline $13 \mathrm{CC}$ & - & - & & & & & \\
\hline
\end{tabular}


Table 2. Cont.

\begin{tabular}{|c|c|c|c|c|c|c|c|}
\hline \multirow{2}{*}{ Sample } & \multirow{2}{*}{ mCCDA * } & \multirow{2}{*}{ SKR $^{\circ}$} & \multirow{2}{*}{$\mathrm{CAB} \S$} & \multicolumn{2}{|c|}{ Confirmation Medium CAB } & \multirow{2}{*}{ Oxidase } & \multirow{2}{*}{ Motility } \\
\hline & & & & $41.5^{\circ} \mathrm{C}$, Aerobic & $25^{\circ} \mathrm{C}$, Microaerophilic & & \\
\hline $14 \mathrm{CC}$ & - & - & & & & & \\
\hline 15 CC & - & - & & & & & \\
\hline 16 CC & + & + & + & - & - & + & + \\
\hline $17 \mathrm{CC}$ & + & + & + & - & - & + & + \\
\hline $18 \mathrm{CC}$ & + & + & + & + & + & + & - \\
\hline $19 \mathrm{CC}$ & + & + & + & + & + & + & - \\
\hline $20 \mathrm{CC}$ & + & + & + & + & + & + & - \\
\hline
\end{tabular}

* Modified Charcoal Cefoperazone Deoycholate Agar; ${ }^{\circ}$ Skirrow's medium; ${ }^{\S}$ Columbia agar base.

\section{2. $P C R$ and $q P C R$ Analysis}

New CampyPFw and CampyPRv primers were tested using the end point PCR on DNAs extracted from the bacteria listed in Table S1 before their utilization in qPCR. Only Campylobacter strains produced the expected amplicons of $132 \mathrm{bp}$, confirming the specificity of the primers. Moreover, as expected, the new primers were specific for $C$. jejuni, C. coli, C. lari, and C. upsaliensis strains. Figure 2 shows results obtained for some samples subjected to PCR.

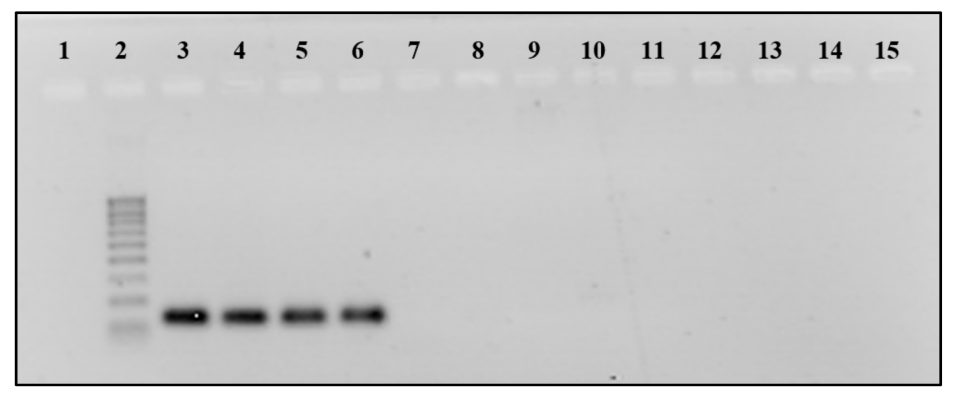

Figure 2. Specificity test with CampyPFW-CampyPRW at $58^{\circ} \mathrm{C}$ annealing temperature. Line 1:-; Line 2: 100 bp DNA Ladder (Sigma. Inc., Milan, Italy); line 3: Campylobacter jejuni DSM 4688; line 4: C. coli DSM 24155; line 5: C. lari DSM 11375; line 6: C. upsaliensis DSM 5365; line 7: C. fetus DSM 5361; line 8: Helicobacter suis DSM 19735; line 9: H. pylori DSM 7492; line 10: H. pylori ICSS; line 11: Arcobacter butzleri DSM 8739; line 12: Bacillus cereus DI4A RC3; line 13: Escherichia coli DISTAM; line 14: Lactobacillus plantarum ATCC RAA 793; line 15: Saccharomyces cerevisiae ATCC 36024.

Primers were then tested in qPCR by using DNA extracted from C. jejuni DSM 4688. The calibration curve obtained using DNA dilutions from $10 \mathrm{ng} / \mu \mathrm{L}$ to $100 \mathrm{fg} / \mu \mathrm{L}$ (Figure 3a) showed a $\mathrm{R}^{2}$ of 0.99 , slope of -3.315 , and efficiency of $100.28 \%$, indicating the high quality of primers. A calibration curve was also performed by using DNA extracted from serial decimal dilutions of C. jejuni DSM 4688 cells in the range from $10^{8}$ to 10 cell $/ \mathrm{mL}$ (Figure 3b). The curve showed a $R^{2}$ of 0.99 , slope of -3.04 , efficiency of $113 \%$, and limit of detection of about $4.6 \times 10^{2}$ cells $/ \mathrm{mL}$.

Table S3 reports the number of cells per milliliter evaluated by using DNA diluted at 1:1000. The cell concentrations extracted from the curve were confirmed by plate count evaluation performed on the same samples.

The qPCR assay was then applied on $\mathrm{CC}_{\mathrm{t} 0}$ and $\mathrm{CC}_{\mathrm{t} 48}$ samples. The obtained results are reported in Table 3. Five chicken samples (2 CC, 3 CC, 8 CC, 10 CC, and 17 CC) were positive for Campylobacter at $\mathrm{t}_{0}$ (before enrichment), and seven (2 CC, $3 \mathrm{CC}, 8 \mathrm{CC}, 9 \mathrm{CC}$, $10 \mathrm{CC}, 16 \mathrm{CC}$, and $17 \mathrm{CC}$ ) at $\mathrm{t}_{48}$ (after enrichment). 

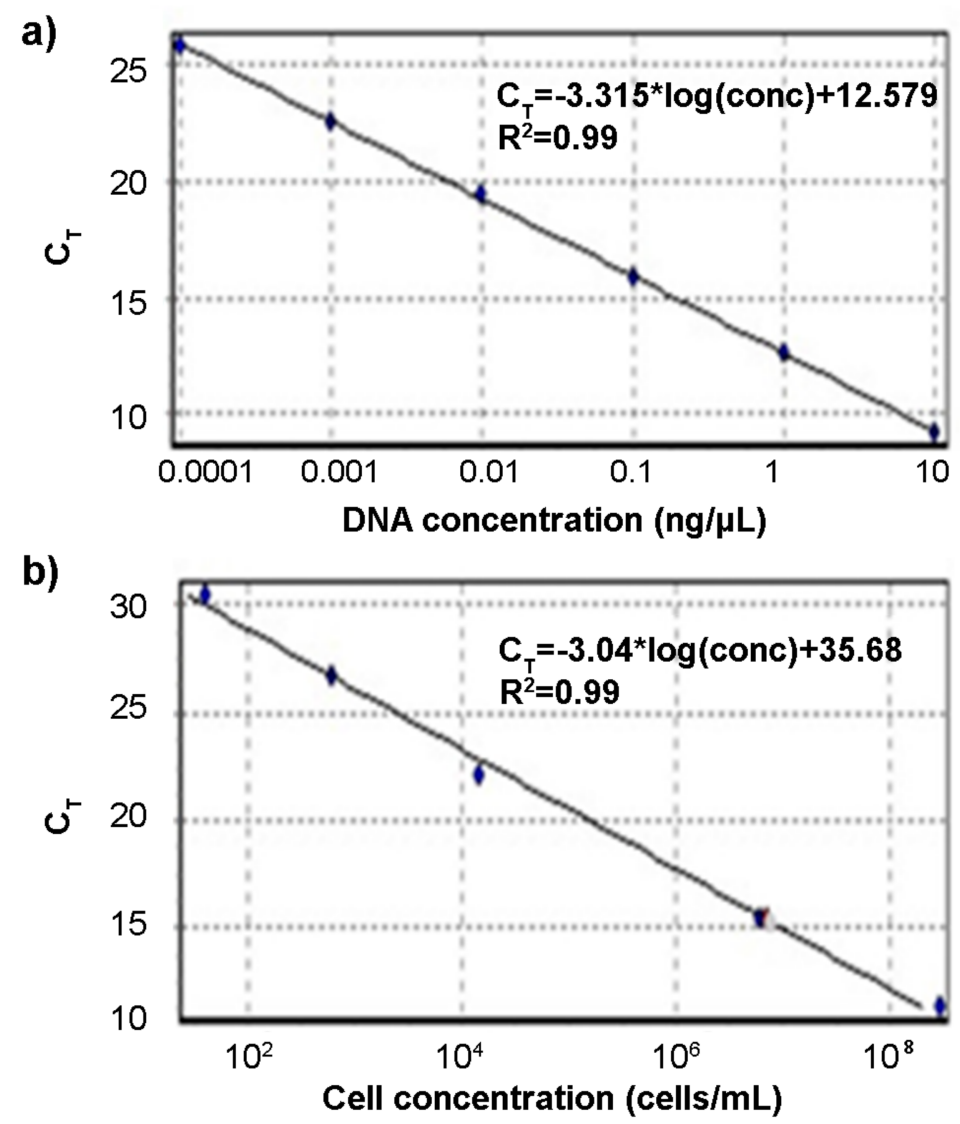

Figure 3. Calibration curves obtained using decimal dilution of DNA (a) and Campylobacter cells (b). (a) Standard curve of serial decimal dilutions of DNA of Campylobacter jejuni DSM 4688. The curve was obtained by plotting the threshold cycle $(\mathrm{Ct})$ of each DNA dilution vs. the DNA concentration $(\mathrm{ng} / \mu \mathrm{L})$. (b) Standard curve of serial decimal dilutions of C. jejuni DSM 4688 cells. The curve was obtained by plotting the $\mathrm{Ct}$ of each cell dilution vs. the cell concentration of $2.09 \times 10^{8}, 7.38 \times 10^{6}$, $2.66 \times 10^{4}$, and $5.9 \times 10^{2} \mathrm{cell} / \mathrm{mL}$.

Table 3. Chicken samples (CC) analysed by qPCR at $\mathrm{t}_{0}$ and at $\mathrm{t}_{48}$. Mean $\mathrm{Ct}$ values with standard deviation (SD); cell quantification expressed in cell/mL; and DNA quantification expressed in $\mathrm{fg} / \mu \mathrm{L}$.

\begin{tabular}{|c|c|c|c|c|c|}
\hline \multirow{2}{*}{$\begin{array}{c}\text { CC } \\
\text { Samples }\end{array}$} & \multicolumn{3}{|c|}{$t_{0}$} & \multicolumn{2}{|c|}{$\mathbf{t}_{48}$} \\
\hline & Mean $\mathrm{Ct} \pm \mathrm{DS}$ & Cell/mL & DNA $\mathrm{fg} / \mathrm{uL}$ & Mean Ct \pm DS & DNA fg/uL \\
\hline $1 \mathrm{CC}$ & $27.55 \pm 0.25$ & - & - & $26.99 \pm 0.16$ & - \\
\hline $2 \mathrm{CC}$ & $24.87 \pm 0.10$ & $3.60 \times 10^{3}$ & $1.96 \times 10^{2}$ & $13.19 \pm 0.19$ & $6.54 \times 10^{5}$ \\
\hline $3 \mathrm{CC}$ & $23.62 \pm 0.38$ & $9.27 \times 10^{3}$ & $4.67 \times 10^{2}$ & $12.97 \pm 0.03$ & $7.62 \times 10^{5}$ \\
\hline $4 \mathrm{CC}$ & $27.45 \pm 0.22$ & - & - & $27.40 \pm 0.23$ & - \\
\hline $5 \mathrm{CC}$ & $28.1 \pm 0.25$ & - & - & $28.15 \pm 0.17$ & \\
\hline $6 \mathrm{CC}$ & $28.3 \pm 0.19$ & - & - & $29.91 \pm 0.09$ & \\
\hline $7 \mathrm{CC}$ & $28.58 \pm 0.42$ & - & - & $28.46 \pm 0.23$ & \\
\hline $8 \mathrm{CC}$ & $23.95 \pm 0.05$ & $7.22 \times 10^{3}$ & $3.71 \times 10^{2}$ & $18.89 \pm 0.10$ & $1.25 \times 10^{4}$ \\
\hline $9 \mathrm{CC}$ & $27.3 \pm 0.19$ & - & - & $22.81 \pm 0.18$ & $8.20 \times 10^{2}$ \\
\hline $10 \mathrm{CC}$ & $25.91 \pm 0.14$ & $1.78 \times 10^{3}$ & $9.59 \times 10^{1}$ & $19.25 \pm 0.25$ & $9.72 \times 10^{3}$ \\
\hline $11 \mathrm{CC}$ & $27.94 \pm 0.18$ & & & $27.72 \pm 0.28$ & \\
\hline $12 \mathrm{CC}$ & $27.58 \pm 0.23$ & - & - & $26.48 \pm 0.09$ & \\
\hline $13 \mathrm{CC}$ & $27.06 \pm 0.10$ & - & - & $26.68 \pm 0.32$ & \\
\hline $14 \mathrm{CC}$ & $27.07 \pm 0.18$ & - & - & $26.82 \pm 0.12$ & \\
\hline $15 \mathrm{CC}$ & $27.34 \pm 0.25$ & - & - & $26.74 \pm 0.10$ & \\
\hline $16 \mathrm{CC}$ & $28.05 \pm 0.15$ & - & - & $25.98 \pm 0.08$ & $9.07 \times 10^{1}$ \\
\hline
\end{tabular}


Table 3. Cont.

\begin{tabular}{|c|c|c|c|c|c|}
\hline \multirow{2}{*}{$\begin{array}{c}\text { CC } \\
\text { Samples }\end{array}$} & \multicolumn{3}{|c|}{$\mathbf{t}_{0}$} & \multicolumn{2}{|c|}{$\mathbf{t}_{48}$} \\
\hline & Mean Ct \pm DS & Cell/mL & DNA fg/uL & Mean Ct \pm DS & DNA fg/uL \\
\hline $17 \mathrm{CC}$ & $25.94 \pm 0.32$ & $1.60 \times 10^{3}$ & $9.32 \times 10^{1}$ & $22.62 \pm 0.32$ & $9.29 \times 10^{2}$ \\
\hline $18 \mathrm{CC}$ & $30.83 \pm 0.39$ & - & - & $27.33 \pm 0.34$ & \\
\hline $19 \mathrm{CC}$ & $28.7 \pm 0.31$ & - & - & $26.96 \pm 0.33$ & \\
\hline $20 \mathrm{CC}$ & $28.41 \pm 0.35$ & - & - & $27.10 \pm 0.32$ & \\
\hline
\end{tabular}

CampyPFw and CampyPRv used in the qPCR assay enabled the detectection of Campylobacter DNA at concentrations as low as $100 \mathrm{fg} / \mu \mathrm{L}$, while previously designed primers needed $10^{3} \mathrm{ng}$ of DNA to provide results as reported by Alves [30]. Similarly, the limit of detection of $4.6 \times 10^{2}$ cells $/ \mathrm{mL}$ obtained using cell dilutions was lower than those previously reported by Wolffs et al. [31], Papic et al. [20], Alves et al. [30], and Wolffs et al. [32], which were $1 \times 10^{3} \mathrm{CFU} / \mathrm{mL}, 2.6 \times 10^{3} \mathrm{CFU} / \mathrm{mL}, 3 \times 10^{3} \mathrm{CFU} / \mathrm{mL}$, and $1.2 \times 10^{3} \mathrm{CFU} / \mathrm{mL}$, respectively. Improved sensitivity obtained by the new primers can be explained by the selected sequence used for primer annealing. CampyPFw and CampyPRv hybridized up to three points in the Campylobacter spp. sequence, as tested with BLAST producing three amplicons of 131-132 bp from 40,908 to 41,039, 396,123 to 396,254, and 700,253 to 700,384 on the DNA sequence CP040608.1 of Campylobacter spp. Moreover, CampyPFw and CampyPRv primers can be used for both PCR and qPCR in contrast to some previously published primers. For instance, Khan et al., [33] designed an efficient couple of primers that can be used only for PCR because their amplicon was too long for qPCR analysis.

The number of Campylobacter cells present in the positive samples was calculated by considering that $100 \mathrm{fg}$ of DNA corresponds to approximately 50 cells [34] and by considering the value obtained by relating the length of the genome of a cell, which is about $1.6 \times 10^{6} \mathrm{bp}$, to the weight of a base pair of 650 Daltons [35]. By hypothesizing that one cell of Campylobacter spp. contains 2 fg of genomic DNA, we refer the DNA value of samples $2 \mathrm{CS}_{\mathrm{t} 0}, 3 \mathrm{CS}_{\mathrm{t} 0}, 8 \mathrm{CS}_{\mathrm{t} 0}, 10 \mathrm{CS}_{\mathrm{t} 0}$, and $17 \mathrm{CS}_{\mathrm{t} 0}$ to about $2.45 \times 10^{3}, 5.84 \times 10^{3}$, $4.64 \times 10^{3}, 1.20 \times 10^{3}$, and $1.17 \times 10^{3}$ cells $/ \mathrm{mL}$, respectively. Campylobacter was present in low numbers in meat samples tested when compared to bacteria such as coliforms and Enterobacteriaceae (Table 1). The high sensitivity and selectivity of primers enabled Campylobacter DNA detection in the presence of meat background bacteria. The data obtained indicate the usefulness of the primer probe set to detect and quantify Campylobacter in naturally contaminated chicken meat (Table 3 ).

Implementation of qPCR methods for the detection of Campylobacter in poultry meat requires optimization regarding both identification and quantification aspects. Although more than $85 \%$ of human campylobacteriosis is caused by C. jejuni, other Campylobacter strains isolated from poultry can also induce infections. The prevalence of C. coli, C. lari, and C. upsaliensis strains was found to be as high as $40 \%, 6 \%$, and $2.5 \%$, respectively, in Campylobacter-positive poultry samples [21,36-39]. The occurrence of non-C. jejuni-C. coli strains is probably even higher because alternative Campylobacter species count for about $10 \%$ of positive isolates [17]. qPCR protocols using new primer probe set designed in this work can simultaneously target the 16S-23S rDNA sequences of C. jejuni, C. coli, C. lari, and C. upsaliensis i.e., the most prevalent Campylobacter strains. Another important improvement is the enhanced sensitivity of detection obtained using the new primers, which enabled bacterial quantification in naturally contaminated chicken meat without an enrichment step. Most of the diagnostics available for the detection of Campylobacter are time-consuming and require the enrichment step, which is not adapted taking into account that chicken meat is consumed within only a few days after preparation. Adding enrichment to a PCR protocol improves the detection rate but impedes bacterial quantification. In addition, the enrichment medium may contain DNA polymerase inhibitors, which can markedly impair Campylobacter detection and quantification. 
The results of the present study suggest that the new primer probe set may improve qPCR protocols for sensitive Campylobacter identification in poultry samples. Its implementation in daily routine analyses still requires validation on a large number of samples. It will be interesting to combine new primers with other optimized qPCR steps that include maximal removal of inhibitors from the matrix, utilization of inhibitor-resistant DNA polymerases, and automated DNA extraction procedure. We believe that in that way a robust qPCR protocol will be obtained for the reliable quantification of Campylobacter needed for surveillance programs to reduce contamination on chicken samples.

\subsection{Sequencing}

The sequences of amplicons obtained with CampyPFw and CampyPRv confirmed the specificity of the primers that detected $C$. jejuni in the analyzed samples with an identity of $99 \%$ and E-Value of zero. Sequencing also confirmed the prevalence of C. jejuni in chicken meat, which is in agreement with the published data [40-42].

\section{Conclusions}

CampyPFw and CampyPRv primers used in this study are specific and sensitive and can be used for real-time quantification of Campylobacter in naturally contaminated chicken samples. The qPCR protocol proposed is simple and rapid and could be directly used to examine chicken meat samples containing low bacterial titers. Since food contamination with Campylobacter is an important food safety concern, this assay can be a useful tool for detecting and monitoring the most prevalent Campylobacter species in contaminated foods.

This couple of primers able to detect the four most widespread Campylobacter species responsible for campylobacteriosis at levels below $10^{3} \mathrm{CFU} / \mathrm{mL}$ and in a amount of reduced time is a potential tool for improving food safety because samples contaminated al lower levels can be detected.

We believe that the sensitivity of the test can be further improved to lower numbers of CFU/g of Campylobacter spp. by using larger sample amounts (e.g., $25 \mathrm{~g}$ ) in order to have a sufficient number of bacteria for detection despite their low absolute concentration, or it can be further improved by increasing the volume of DNA used as a template in PCR assays.

Supplementary Materials: The following are available online at https:/ /www.mdpi.com/article/10 .3390 / foods10102341/s1, Table S1: Microorganisms used in the work; Table S2: Accession number of the sequences analyzed in silico to design primers CampyPFw and CampyPRv; Table S3: Data obtained with chicken meat samples artificially spiked with Campylobacter jejuni.

Author Contributions: Conceptualization, M.M.; methodology, M.M.; validation, P.V.; formal analysis, P.V.; investigation, P.V.; resources, M.M.; data curation, P.V. and M.M.; writing-original draft preparation, P.V. and J.V.; writing—review and editing, P.V., J.V., and M.M.; visualization, P.V. and J.V.; supervision, M.M.; project administration, M.M.; funding acquisition, J.V. and M.M. All authors have read and agreed to the published version of the manuscript.

Funding: This research was supported in part by the University Paris-Saclay through the Poc in labs 2019, grant agreement No. 00003469 (OSCAR), to J.V.

Institutional Review Board Statement: Not applicable.

Informed Consent Statement: Not applicable.

Data Availability Statement: Not applicable.

Acknowledgments: The authors would like to thank the students Andrea Anzil, Francesca Maran, Francesca Caon, and Giulia Cristin (University of Udine, Udine, Italy) for their help with data collection.

Conflicts of Interest: The authors declare no conflict of interest. 


\section{References}

1. Vizzini, P.; Braidot, M.; Vidic, J.; Manzano, M. Electrochemical and optical biosensors for the detection of campylobacter and listeria: An update look. Micromachines 2019, 10, 500. [CrossRef] [PubMed]

2. Scallan Walter, E.J.; Crim, S.M.; Bruce, B.B.; Griffin, P.M. Incidence of Campylobacter-associated Guillain-Barre Syndrome estimated from health insurance data. Foodborne Pathog. Dis. 2020, 17, 23-28. [CrossRef] [PubMed]

3. He, Y.; Yao, X.; Gunther, N.W.; Xie, Y.; Tu, S.-I.; Shi, X. Simultaneous detection and differentiation of Campylobacter jejuni, C. coli, and C. lari in chickens using a multiplex real-time PCR assay. Food Anal. Methods 2010, 3, 321-329. [CrossRef]

4. Nastasijevic, I.; Proscia, F.; Boskovic, M.; Glisic, M.; Blagojevic, B.; Sorgentone, S.; Kirbis, A.; Ferri, M. The European Union control strategy for Campylobacter spp. in the broiler meat chain. J. Food Saf. 2020, 40, e12819. [CrossRef]

5. El-Shibiny, A.; Scott, A.; Timms, A.; Metawea, Y.; Connerton, P.; Connerton, I. Application of a group II Campylobacter bacteriophage to reduce strains of Campylobacter jejuni and Campylobacter coli colonizing broiler chickens. J. Food Prot. 2009, 72, 733-740. [CrossRef]

6. $\quad$ Stingl, K.; Knüver, M.-T.; Vogt, P.; Buhler, C.; Krüger, N.-J.; Alt, K.; Tenhagen, B.-A.; Hartung, M.; Schroeter, A.; Ellerbroek, L. Quo vadis?-Monitoring Campylobacter in Germany. Eur. J. Microbiol. Immunol. 2012, 2, 88-96. [CrossRef]

7. Haddad, N.; Burns, C.M.; Bolla, J.M.; Prévost, H.; Fédérighi, M.; Drider, D.; Cappelier, J.M. Long-term survival of Campylobacter jejuni at low temperatures is dependent on polynucleotide phosphorylase activity. Appl. Environ. Microbiol. 2009, 75, 7310-7318. [CrossRef]

8. Vidic, J.; Manzano, M.; Chang, C.-M.; Jaffrezic-Renault, N. Advanced biosensors for detection of pathogens related to livestock and poultry. Vet. Res. 2017, 48, 1-22. [CrossRef]

9. Vizzini, P.; Manzano, M.; Farre, C.; Meylheuc, T.; Chaix, C.; Ramarao, N.; Vidic, J. Highly sensitive detection of Campylobacter spp in chicken meat using a silica nanoparticle enhanced dot blot DNA biosensor. Biosens. Bioelectron. 2020, 171, 112689. [CrossRef]

10. Vidic, J.; Vizzini, P.; Manzano, M.; Kavanaugh, D.; Ramarao, N.; Zivkovic, M.; Radonic, V.; Knezevic, N.; Giouroudi, I.; Gadjanski, I. Point-of-need DNA testing for detection of foodborne pathogenic bacteria. Sensors 2019, 19, 1100. [CrossRef]

11. Ricke, S.C.; Feye, K.M.; Chaney, W.E.; Shi, Z.; Pavlidis, H.; Yang, Y. Developments in rapid detection methods for the detection of foodborne campylobacter in the United States. Front. Microbiol. 2019, 9, 3280. [CrossRef] [PubMed]

12. Botteldoorn, N.; van Coillie, E.; Piessens, V.; Rasschaert, G.; Debruyne, L.; Heyndrickx, M.; Herman, L.; Messens, W. Quantification of Campylobacter spp. in chicken carcass rinse by real-time PCR. J. Appl. Microbiol. 2008, 105, 1909-1918. [CrossRef] [PubMed]

13. Duarte, A.; Botteldoorn, N.; Coucke, W.; Denayer, S.; Dierick, K.; Uyttendaele, M. Effect of exposure to stress conditions on propidium monoazide (PMA)-qPCR based Campylobacter enumeration in broiler carcass rinses. Food Microbiol. 2015, 48, 182-190. [CrossRef]

14. Josefsen, M.H.; Löfström, C.; Hansen, T.B.; Christensen, L.S.; Olsen, J.E.; Hoorfar, J. Rapid quantification of viable Campylobacter bacteria on chicken carcasses, using real-time PCR and propidium monoazide treatment, as a tool for quantitative risk assessment. Appl. Environ. Microbiol. 2010, 76, 5097-5104. [CrossRef]

15. Englen, M.D.; Kelley, L.C. A rapid DNA isolation procedure for the identification of Campylobacter jejuni by the polymerase chain reaction. Lett. Appl. Microbiol. 2000, 31, 421-426. [CrossRef]

16. Reis, L.P.; Menezes, L.D.M.; Lima, G.K.; Santos, E.L.D.S.; Dorneles, E.M.S.; Assis, D.C.S.D.; Lage, A.P.; Cançado, S.D.V.; Figueiredo, T.C.D. Detection of Campylobacter spp. in chilled and frozen broiler carcasses comparing immunoassay, PCR and real time PCR methods. Ciência Rural 2018, 48, e20161034. [CrossRef]

17. De Boer, P.; Rahaoui, H.; Leer, R.; Montijn, R.; van der Vossen, J. Real-time PCR detection of Campylobacter spp.: A comparison to classic culturing and enrichment. Food Microbiol. 2015, 51, 96-100. [CrossRef]

18. Lund, M.; Nordentoft, S.; Pedersen, K.; Madsen, M. Detection of Campylobacter spp. in chicken fecal samples by real-time PCR. J. Clin. Microbiol. 2004, 42, 5125-5132. [CrossRef]

19. Ivanova, M.; Singh, R.; Dharmasena, M.; Gong, C.; Krastanov, A.; Jiang, X. Rapid identification of Campylobacter jejuni from poultry carcasses and slaughtering environment samples by real-time PCR. Poult. Sci. 2014, 93, 1587-1597. [CrossRef] [PubMed]

20. Papić, B.; Pate, M.; Henigman, U.; Zajc, U.; Gruntar, I.; Biasizzo, M.; Ocepek, M.; Kušar, D. New approaches on quantification of Campylobacter jejuni in poultry samples: The use of digital PCR and real-time PCR against the ISO standard plate count method. Front. Microbiol. 2017, 8, 331. [CrossRef] [PubMed]

21. Schnider, A.; Overesch, G.; Korczak, B.; Kuhnert, P. Comparison of real-time PCR assays for detection, quantification, and differentiation of Campylobacter jejuni and Campylobacter coli in broiler neck skin samples. J. Food Prot. 2010, 73, 1057-1063. [CrossRef] [PubMed]

22. Borges, K.A.; Cisco, I.C.; Furian, T.Q.; Tedesco, D.C.; Rodrigues, L.B.; Do Nascimento, V.P.; dos Santos, L.R. Detection and quantification of Campylobacter spp. in Brazilian poultry processing plants. J. Infect. Dev. Ctries. 2020, 14, 109-113. [CrossRef] [PubMed]

23. Cocolin, L.; Aggio, D.; Manzano, M.; Cantoni, C.; Comi, G. An application of PCR-DGGE analysis to profile the yeast populations in raw milk. Int. Dairy J. 2002, 12, 407-411. [CrossRef]

24. Manzano, M.; Cocolin, L.; Cantoni, C.; Comi, G. Bacillus cereus, Bacillus thuringiensis and Bacillus mycoides differentiation using a PCR-RE technique. Int. J. Food Microbiol. 2003, 81, 249-254. [CrossRef]

25. Corpet, F. Multiple sequence alignment with hierarchical clustering. Nucleic Acids Res. 1988, 16, 10881-10890. [CrossRef] [PubMed] 
26. Vizzini, P.; Beltrame, E.; Zanet, V.; Vidic, J.; Manzano, M. Development and Evaluation of qPCR Detection Method and Zn$\mathrm{MgO} /$ Alginate Active Packaging for Controlling Listeria monocytogenes Contamination in Cold-Smoked Salmon. Foods 2020, 9 , 1353. [CrossRef]

27. Klijn, N.; Weerkamp, A.H.; de Vos, W.M. Identification of mesophilic lactic acid bacteria by using polymerase chain reactionamplified variable regions of 16S rRNA and specific DNA probes. Appl. Environ. Microbiol. 1991, 57, 3390-3393. [CrossRef]

28. Altschul, S.F.; Gish, W.; Miller, W.; Myers, E.W.; Lipman, D.J. Basic local alignment search tool. J. Mol. Biol. 1990, 215, 403-410. [CrossRef]

29. Fontanot, M.; Iacumin, L.; Cecchini, F.; Comi, G.; Manzano, M. Rapid detection and differentiation of important Campylobacter spp. in poultry samples by dot blot and PCR. Food Microbiol. 2014, 43, 28-34. [CrossRef]

30. Alves, J.; Hirooka, E.Y.; de Oliveira, T.C.R.M. Development of a multiplex real-time PCR assay with an internal amplification control for the detection of Campylobacter spp. and Salmonella spp. in chicken meat. LWT Food Sci. Technol. 2016, 72, 175-181. [CrossRef]

31. Wolffs, P.; Norling, B.R.; Hoorfar, J.; Griffiths, M.; Rådström, P. Quantification of Campylobacter spp. in chicken rinse samples by using flotation prior to real-time PCR. Appl. Environ. Microbiol. 2005, 71, 5759-5764. [CrossRef]

32. Wolffs, P.F.; Glencross, K.; Norling, B.; Griffiths, M.W. Simultaneous quantification of pathogenic Campylobacter and Salmonella in chicken rinse fluid by a flotation and real-time multiplex PCR procedure. Int. J. Food Microbiol. 2007, 117, 50-54. [CrossRef] [PubMed]

33. Khan, I.; Edge, T. Development of a novel triplex PCR assay for the detection and differentiation of thermophilic species of Campylobacter using 16S-23S rDNA internal transcribed spacer (ITS) region. J. Appl. Microbiol. 2007, 103, 2561-2569. [CrossRef] [PubMed]

34. Pacholewicz, E.; Swart, A.; Lipman, L.J.; Wagenaar, J.A.; Havelaar, A.H.; Duim, B. Propidium monoazide does not fully inhibit the detection of dead Campylobacter on broiler chicken carcasses by qPCR. J. Microbiol. Methods 2013, 95, 32-38. [CrossRef] [PubMed]

35. Rédei, G.P. Genetics Manual: Current Theory, Concepts, Terms; World Scientific: Singapore, 1998.

36. Osimani, A.; Aquilanti, L.; Pasquini, M.; Clementi, F. Prevalence and risk factors for thermotolerant species of Campylobacter in poultry meat at retail in Europe. Poult. Sci. 2017, 96, 3382-3391. [CrossRef] [PubMed]

37. Rasschaert, G.; Houf, K.; van Hende, J.; De Zutter, L. Campylobacter contamination during poultry slaughter in Belgium. J. Food Prot. 2006, 69, 27-33. [CrossRef]

38. Lynch, Ó.A.; Cagney, C.; McDowell, D.A.; Duffy, G. Occurrence of fastidious Campylobacter spp. in fresh meat and poultry using an adapted cultural protocol. Int. J. Food Microbiol. 2011, 150, 171-177. [CrossRef] [PubMed]

39. Sinulingga, T.S.; Aziz, S.A.; Bitrus, A.A.; Zunita, Z.; Abu, J. Occurrence of Campylobacter species from broiler chickens and chicken meat in Malaysia. Trop. Anim. Health Prod. 2020, 52, 151-157. [CrossRef]

40. Di Giannatale, E.; Calistri, P.; Di Donato, G.; Decastelli, L.; Goffredo, E.; Adriano, D.; Mancini, M.E.; Galleggiante, A.; Neri, D.; Antoci, S. Thermotolerant Campylobacter spp. in chicken and bovine meat in Italy: Prevalence, level of contamination and molecular characterization of isolates. PLoS ONE 2019, 14, e0225957. [CrossRef]

41. Szosland-Fałtyn, A.; Bartodziejska, B.; Krolasik, J.; Paziak-Domańska, B.; Korsak, D.; Chmiela, M. The prevalence of Campylobacter spp. in Polish poultry meat. Pol. J. Microbiol. 2018, 67, 117-120. [CrossRef]

42. Korsak, D.; Maćkiw, E.; Rożynek, E.; Żyłowska, M. Prevalence of Campylobacter spp. in retail chicken, turkey, pork, and beef meat in Poland between 2009 and 2013. J. Food Prot. 2015, 78, 1024-1028. [CrossRef] [PubMed] 